\title{
In vitro Influence of Salinity Stress on Callus and Plantlets Regeneration of Apple Rootstocks
}

\author{
A. O. Rayan \\ Fruit and Ornamentals Breeding Department, Horticulture \\ Research Institute, Agricultural Research Centre, Cairo, Egypt.
}

\begin{abstract}
T $\mathrm{N}$ this investigation a screening of two apple rootstocks (Balady and MM 106) to salinity, stress was achieved for an attempt to introduce more tolerant apple rootstocks. Calluses of the two rootstocks were cultured on MS medium supplemented with $\mathrm{NaCl}$ as a source of salinity at five concentrations $(0.00,500,1000,2000,3000$ $\mathrm{mg} / \mathrm{l})$. Morphological characteristics of both apple rootstocks Balady and MM106, negatively responded to the raising of $\mathrm{NaCl}$ concentrations in vitro such as callus survival and regeneration percentages, plantlets length $(\mathrm{cm})$, number of multiple shoots, number of leaves/plant, number of roots/plant and root length $(\mathrm{cm})$. The higher salinity concentration $(3000 \mathrm{mg} / \mathrm{l} \mathrm{NaCl})$ induced the lowest significant percentage of callus survival, especially with MM 106 (32.0 $\%)$ if compared with control $(60.0 \%)$. The mean of regeneration percentage reached the maximum number with control (38.67\%), and decreased gradually with higher $\mathrm{NaCl}$ concentrations until it was (23.67\%) with $3000 \mathrm{mg} / \mathrm{l}$. It was feasible that salinity did not reduce the average length of shoots. Number of multiple shoots was affected by raising salinity level into medium. The highest significant value was obtained with control $(0.00 \mathrm{NaCl})(14.00)$ while, the lowest significant Value was (8.50) with $3000 \mathrm{mg} / \mathrm{l}$. Moreover, number of leaves per plant, were reduced under salinity stress, which $(0.00$ and $500 \mathrm{mg} / \mathrm{l} \mathrm{NaCl}$ ) treatments achieved the highest significant number of leaves Values (8.83 and 7.83), respectively, followed by $1000 \mathrm{mg} / \mathrm{l}$ (7.33). Balady was more tolerant than MM 106 to salinity stress and the average number of roots was (6.27 and 4.80), respectively. The proline concentration in rootstock increased with the raising of salt concentration, meanwhile, total chlorophyll content decreased by the increasing of salt concentration in the culture medium. On the other hand, peroxidase, poly phenyl oxidase, alcohol dehydrogenase and malate dehydrogenase isozymes banding patterns represent differences in some bands density or absent bands with different $\mathrm{NaCl}$ concentrations if compared with control treatment.
\end{abstract}

Keywords: Apple rootstock, Callus, In vitro, Isozyme, $\mathrm{NaCl}$, Regeneration, Salt stress.

Apple is one of the major recommended fruit crops for new reclaimed soils in Egypt. Salinity is a critical problem facing agriculture, especially in irrigated lands located in semiarid zones. Soil salinity considered one of the most important abiotic stresses that limits plant growth and yield of most crops. (Zhu, 2001 and Chinnusamy et al., 2005). 
Resistance to abiotic stresses such as drought, salinity and alkalinity is an important trait for selection of fruit trees rootstocks, which affect the nutritional status of the scion and appreciably influence scion tolerance to salinity (Sotiropoulos et al., 2006).

Producing sustainable and profitable crops under these conditions needs technological and biological approaches, including selection of new and more salt tolerant cultivars of named plants using conventional breeding programs or tissue culture techniques (Ashraf \& Akram, 2009 and Ashraf et al., 2012). Therefore, developing rootstocks that tolerate different biotic and abiotic stresses is one of the major goals of breeding programs of apple rootstocks to insure roots tocks suitable for different environmental conditions (Ryugo, 1988).

Tissue culture technique is an ideal tool for obtaining salt tolerant plants offering potential for quick screening of germplasm against salt stress (Vijayan et al., 2003 and Molassiotis et al., 2006). Screening or evaluation methods involving in vitro shoot culture have proven to be better applicable system for testing salt tolerance and were used in several plants such as grape (Sivritepe and Eris, 1999), "Gisela 5" (Prunus cerasus $\times$ Prunus canescens) sweet cherry roots tock (Erturk et al., 2007), quince (Vitaglino et al., 1992), Nemagard (Prunus perisca) and GF677 (Prunus persica $\times$ Prunus amygdalus) rootstocks (Sotiropoulos et al., 2006) and apple rootstocks (Therios \& Misopolinos, 1989 and Sotiropoulos et al., 2005).

Is ozyme markers provide a convenient method for detecting genetic changes and offer a possible method for cultivars and rootstocks identification. In apple, isozymes have been used as biochemical markers for the identification of clonal apple rootstocks (Batlle and Aleston, 1994).

Thus, the objective of this study was to investigate the growth under salt stress at callus and regeneration of two apple rootstocks (Balady and MM106), and attempt to introduce more tolerant apple roots tocks.

\section{Materials and Methods}

This work was conducted in the laboratory of Fruit and Ornamentals Breeding Dept., Hort. Res. Inst., Agric. Res. Center, Giza, Egypt. All tissue culture experiments were carried out during 2013 and 2014 seasons.

\section{Plant materials}

Two apple rootstocks (Malus domestica Borkh) MM106 and Balady which are the most common rootstocks in Egypt were used. There leaves were used as source of explants for callus initiation, regeneration, multiplication and rooting. Leaves were washed with tap water and sterilized by immersion in $70 \%$ ethanol for $5 \mathrm{~min}$, followed by immersion in $20 \%$ sodium hypochlorite supplemented with $150 \mathrm{mg} / \mathrm{l}$ of ascorbic acid for $20 \mathrm{~min}$., then rinsed four times each for ten min., in sterile distilled water supplemented with $150 \mathrm{mg} / \mathrm{l}$ of ascorbic acid.

Egypt. J. Hort. Vol. 42, No. 1 (2015) 


\section{Mode of excision}

Margins of expanded leaves (10-12 mm long) were removed and the remaining part was cut transversely to the midrib into two portions. Then the leaf portions were dissected into small pieces $(0.3 \mathrm{~cm})$ and placed with the adaxial surface in contact with different MS media (Murashige and Skoog, 1962).

Culture conditions, Callus induction, regeneration and rooting

Leaf segments were placed with the adaxial surface in contact with MS medium supplemented with $3 \%$ sucrose, $0.7 \%$ agar, $1.0 \mathrm{mg} / 1 \mathrm{BA}, 0.5 \mathrm{mg} / \mathrm{IBA}$ and the $\mathrm{pH}$ was adjusted to 5.6. Explants were grown at $25^{\circ} \mathrm{C}$ using $16 \mathrm{~h}$ light photoperiod with a light intensity of 2000 lux provided by cool white fluorescent tubes. For in vitro salt stress, Callus were then cultured in MS medium supplemented with $0.00,500,1000,2000$ and $3000 \mathrm{mg} / 1 \mathrm{NaCl}$ as a source of salinity. The subculture was performed every four weeks using the same medium. Then the maintained calluses were transferred to the same previous MS medium supplemented with $2.0 \mathrm{mg} / \mathrm{l} \mathrm{BA}$ and $0.5 \mathrm{mg} / \mathrm{l} \mathrm{IBA}$ for plant regeneration. Number of shoots per callus pieces was recorded after two months from transferring the callus to the regeneration medium. Multiple shoots were separated and transferred vertically on $1 / 2 \mathrm{MS}$ medium supplemented with $2 \%$ sucrose, $0.7 \%$ agar, $0.5 \mathrm{mg} / \mathrm{l}$ IBA and the $\mathrm{pH}$ was adjusted to 5.6 as a rooting medium for another 4 weeks.

\section{The following data were recorded}

Vegetative growth/plant

Percentage of survival and regeneration of callus, Plantlet length $(\mathrm{cm})$, number of multiple shoots, number of leaves/plant, number of roots/plant, root length $(\mathrm{cm})$.

\section{Chemical analysis}

Total chlorophyll: Total chlorophyll was determined using chlorophyll meter (Model SPAD-502). Total chlorophyll was estimated as $\mu \mathrm{g} / \mathrm{cm}^{2}$.

Proline determination: The proline content was determined according to the method described by Bates et al. (1973).

\section{Isozymes electrophoresis}

Extraction of isozymes was done as described by Jonathan and Weeden (1990). Native-polyacrylamide gel electrophoresis (Native-PAGE) was performed on $12 \%(\mathrm{~W} / \mathrm{V})$ slab gels, then, gels were stained according to Wendel and Weeden (1989) for isozymes of peroxidase (Px), poly phenyl oxidase (PPO), alcohol dehydrogenase (Adh) and malate dehydrogenase (Mdh). The stained gels were incubated at $37^{\circ} \mathrm{C}$ in dark conditions for complete staining after adding the appropriate substrates and staining solutions. Gel bands were scanned and analyzed using Gel Doc., Bio-Rad system.

\section{Statistical Analysis}

Experiments were set in completely randomized design. Each treatment was performed in ten jars containing five explants and each experiment was replicated three times. Data were subjected to analysis of variance. Duncan's 
multiple range test at $5 \%$ level of significance $(\mathrm{p}=0.05)$, was used for means comparis ons according to (Snedecor and Cochran, 1980).

\section{Results and Discussions}

Effect of salinity stress on callus and vegetative growth characteristics of Balady and MM106 apple rootstocks

Data in Table 1 and Fig. 1 showed that salinity greatly affected survival percentages of callus in both rootstocks. At $(3000 \mathrm{mg} / 1 \mathrm{NaCl})$, the mean of callus significantly decreased $(37.83 \%)$ if compared with control $(60.00 \%)$. The salinity was more harmful to MM106 rootstock (44.47\%) than Balady rootstock $(51.40 \%)$. Interactions between salinity and rootstocks showed that, the higher salinity concentration $(3000 \mathrm{mg} / \mathrm{l})$ induced the lowest significant percentage of callus especially with MM106 (32.0\%) if compared with control (60.00\%). The ability of Balady and MM106 rootstocks to renew growth was affected under the stress conditions of different salinity levels as $\mathrm{NaCl}$. The mean of regeneration percentage reached the maximum number with control (38.67\%), and decreased gradually with higher $\mathrm{NaCl}$ concentrations until it was $(23.67 \%)$ with $3000 \mathrm{mg} / \mathrm{l}$. MM106 rootstock was affected by salinity treatments $(25.27 \%)$ more than Balady $(35.73 \%)$. Concerning interactions between salinity and rootstocks it was prevailed that, the regeneration percentage was high significantly with Balady rootstock cultured on $0.00 \mathrm{NaCl}(42.00 \%)$, while, the lowest significant mean was obtained with MM106 cultured on $3000 \mathrm{mg} / \mathrm{l}(18.00 \%)$.

It was feasible that salinity did not reduce the average length of shoots. Concentration of $500 \mathrm{mg} / \mathrm{l}$ gave the highest value of shoot length $(5.43 \mathrm{~cm})$. However, significant difference detected between rootstocks, Balady rootstock gave the higher significant value $(4.88 \mathrm{~cm})$ if compared with MM106 $(4.07 \mathrm{~cm})$. Regarding the interactions between rootstocks, Balady achieved the highest significant mean $(6.46 \mathrm{~cm})$ at $500 \mathrm{mg} / \mathrm{l}$, if compared with other treatments, which resulted in insignificant differences.

In addition, Table 1 and Fig. 1 showed that the number of multiple shoots was affected by raising salinity level into medium. The highest significant mean was obtained with control $(0.00 \mathrm{NaCl})(14.00)$ while, the lowest significant mean was (8.50) with $3000 \mathrm{mg} / \mathrm{l}$. Salinity was more effective on MM106 than Balady rootstock. Concerning the interaction between both rootstocks and Balady, the control gave the highest significant mean (16.00) if compared with other treatments. While, the lowest significant mean achieved with MM106 rootstock at $3000 \mathrm{mg} / \mathrm{l}(6.67)$.

Salinity affected the number of leaves per plant, which $(0.00$ and $500 \mathrm{mg} / \mathrm{l}$ $\mathrm{NaCl})$ treatments achieved the highest significant number of leaves means $(8.83$ and 7.83), respectively, followed by $1000 \mathrm{mg} / \mathrm{l}$ (7.33). Whereas, the lowest significant number was recorded at 2000 and $3000 \mathrm{mg} / \mathrm{l}$ with insignificant differences (6.16 and 5.83), respectively. Balady rootstock gave the highest significant mean (7.67) compared with MM106 (6.73).

Egypt. J. Hort. Vol. 42, No. 1 (2015) 
As shown in Table 1 and Fig. 2 salinity had a clear significant effect on the average number of roots per plantlet. The highest significant value was achieved with control $(0.00 \mathrm{NaCl})(6.83)$, while the lowest significant value was recorded with $3000 \mathrm{mg} / \mathrm{l}$ (4.33). Rootstocks showed the same trend, Balady was more tolerant than MM106 to salinity stress and the mean number of roots was $(6.27$ and 4.80), respectively. The interactions between studied variables revealed significant differences in number of roots of both rootstocks grown in $(0.00$ $\mathrm{NaCl})$ (7.00 and 6.67), respectively. The lowest significant (3.66 and 3.66) was recorded with MM106 rootstock cultured on 2000 and $3000 \mathrm{mg} / \mathrm{l}$, respectively.

Data in Table 1 and Fig. 2 showed the effect of exposure to salinity in vitro on the root length, control $(0.00 \mathrm{NaCl})$ and $500 \mathrm{mg} / \mathrm{l}$ treatments were recorded the highest significant mean of root length $(7.02$ and $6.83 \mathrm{~cm})$, respectively. While, the lowest significant mean were recorded with $2000 \mathrm{mg} / 1(5.73 \mathrm{~cm})$ followed by $3000 \mathrm{mg} / 1(5.53 \mathrm{~cm})$. The rootstocks means cleared that Balady produced significant length of roots $(6.67 \mathrm{~cm})$ compared with MM106 (5.92 $\mathrm{cm})$. The interactions cleared that the highest significant mean of root length was achieved with Balady rootstock cultured on $(0.00 \mathrm{NaCl})$. While, the lowest significant means $(5.30$ and $5.20 \mathrm{~cm})$ were recorded with MM106 cultured on $2000 \mathrm{mg} / \mathrm{l}$ followed by $3000 \mathrm{mg} / \mathrm{l} \mathrm{NaCl}$, respectively. MM106 rootstock showed more sensitivity to salt stress. These results are agree with those found by Naeniei et al. (2006) who, reported that increasing salinity caused reduction of stem length, leaf surface, number of internodes and its length of pomegranate "Malas Torsh" and "Alak Torsh" cultivars when its rooted cuttings were planted in pots under levels of salinity up to $120 \mathrm{mM}$. While, the growth rate of pomegranate "Malas Shirin" cv. increased with raising salinity level up to $40 \mathrm{mM}$., and El-Agamy et al. (2010), who found that, survival percentage, plantlet height, average leaves number, average number of nodes, average internode length and fresh and dry weight were significantly decreased using 6.0 and $8.0 \mathrm{~g} / 1 \mathrm{NaCl}$ if compared with control treatment. Moreover, Rayan and Awad (2013) stated that no survival calluses were obtained at $5000 \mathrm{mg} / \mathrm{l}$ of $\mathrm{NaCl}$ of in vitro pear (Pyrus Communis var. Betulifolia) explants. Regenerated plants were also decreased with the increasing of salt concentration. $\mathrm{NaCl}$ at $1000 \mathrm{mg} / \mathrm{l}$ concentration revealed high morphological measurements if compared with control treatment, while, the opposite was true for the 2000, 3000 and $4000 \mathrm{mg} / \mathrm{l}$ concentrations.

Effect of salinity stress on proline accumulation and total chlorophyll of Balady and MM106 rootstocks' growth characteristics

Figure 3 showed the effect of salinity stress on proline accumulation and total chlorophyll of Balady and MM106 rootstocks. The root analyses of Balady and MM106 plantlets under increasing $\mathrm{NaCl}$ concentrations showed that proline concentration was increased with raising $\mathrm{NaCl}$ concentration in the culture medium. At the highest concentration $(3000 \mathrm{mg} / \mathrm{l})$ of $\mathrm{NaCl}$, the proline was 11.66 and 10.95 if compared with control $(0.00 \mathrm{NaCl})$ which was 5.33 and 5.12 for Balady and MM106 rootstocks, respectively. On the other hand, total chlorophyll was decreased when salt concentration increased as shown in Fig. 3. 
TABLE 1. In vitro salinity effect as $\mathrm{NaCl}(\mathrm{mg} / \mathrm{l})$ at different concentrations on callus and plantlets vegetative growth characteristics of Balady and MM106 rootstock.

\begin{tabular}{|c|c|c|c|c|}
\hline Traits in tissue culture & $\begin{array}{c}\mathrm{NaCl} \\
\mathrm{mg} / \mathrm{l}\end{array}$ & Balady & MM 106 & Means \\
\hline \multirow{6}{*}{$\begin{array}{c}\text { Percentage of callus } \\
\text { survival }\end{array}$} & Control & $60.00 \mathrm{a}$ & $60.00 \mathrm{a}$ & $60.00 \mathrm{~A}$ \\
\hline & 500 & $54.00 \mathrm{~b}$ & $50.67 \mathrm{bc}$ & $52.33 \mathrm{~B}$ \\
\hline & 1000 & $51.67 \mathrm{~b}$ & $44.00 \mathrm{~d}$ & $47.83 \mathrm{C}$ \\
\hline & 2000 & $47.67 \mathrm{c}$ & $35.67 \mathrm{e}$ & $41.67 \mathrm{D}$ \\
\hline & 3000 & $43.67 \mathrm{~d}$ & $32.00 \mathrm{f}$ & $37.83 \mathrm{E}$ \\
\hline & Means & $51.40 \mathrm{~A}^{\prime \prime}$ & $44.47 \mathrm{~B}^{\prime \prime}$ & \\
\hline \multirow{6}{*}{$\begin{array}{l}\text { Percentage of } \\
\text { regeneration }\end{array}$} & Control & $42.00 \mathrm{a}$ & $35.33 \mathrm{bc}$ & $38.67 \mathrm{~A}$ \\
\hline & 500 & $36.33 \mathrm{ab}$ & $29.67 \mathrm{~b}-\mathrm{d}$ & $33.00 \mathrm{~B}$ \\
\hline & 1000 & $36.33 \mathrm{ab}$ & $23.33 \mathrm{de}$ & $29.83 \mathrm{BC}$ \\
\hline & 2000 & $34.67 \mathrm{bc}$ & $20.00 \mathrm{e}$ & $27.33 \mathrm{CD}$ \\
\hline & 3000 & $29.33 \mathrm{~cd}$ & $18.00 \mathrm{e}$ & $23.67 \mathrm{D}$ \\
\hline & Means & $35.73 \mathrm{~A}^{\prime \prime}$ & $25.27 \mathrm{~B}^{\prime \prime}$ & \\
\hline \multirow{6}{*}{ Plantlet length $(\mathrm{cm})$} & Control & $4.83 \mathrm{~b}$ & $4.80 \mathrm{~b}$ & $4.817 \mathrm{AB}$ \\
\hline & 500 & $6.46 \mathrm{a}$ & $4.40 \mathrm{~b}$ & $5.43 \mathrm{~A}$ \\
\hline & 1000 & $4.63 \mathrm{~b}$ & $4.13 \mathrm{~b}$ & $4.38 \mathrm{AB}$ \\
\hline & 2000 & $4.46 \mathrm{~b}$ & $3.70 \mathrm{~b}$ & $4.08 \mathrm{~B}$ \\
\hline & 3000 & $4.00 \mathrm{~b}$ & $3.33 \mathrm{~b}$ & $3.66 \mathrm{~B}$ \\
\hline & Means & $4.88 \mathrm{~A}^{\prime \prime}$ & $4.07 \mathrm{~B}^{\prime \prime}$ & \\
\hline \multirow{6}{*}{ No. of multiple shoots } & Control & $16.00 \mathrm{a}$ & $12.00 \mathrm{~b}-\mathrm{d}$ & $14.00 \mathrm{~A}$ \\
\hline & 500 & $14.00 \mathrm{ab}$ & $10.00 \mathrm{~d}-\mathrm{f}$ & $12.00 \mathrm{~B}$ \\
\hline & 1000 & $13.67 \mathrm{ab}$ & $8.66 \mathrm{e}-\mathrm{g}$ & $11.17 \mathrm{BC}$ \\
\hline & 2000 & $12.67 \mathrm{bc}$ & $7.66 \mathrm{fg}$ & $10.17 \mathrm{C}$ \\
\hline & 3000 & $10.33 \mathrm{c}-\mathrm{e}$ & $6.67 \mathrm{~g}$ & $8.50 \mathrm{D}$ \\
\hline & Means & $13.33 \mathrm{~A}^{\prime \prime}$ & $9.00 \mathrm{~B}^{\prime \prime}$ & \\
\hline \multirow{6}{*}{ No. of leaves/plantlets } & Control & $9.00 \mathrm{a}$ & $8.66 \mathrm{ab}$ & $8.83 \mathrm{~A}$ \\
\hline & 500 & $8.33 \mathrm{ab}$ & $7.33 \mathrm{a}-\mathrm{c}$ & $7.83 \mathrm{AB}$ \\
\hline & 1000 & $7.66 \mathrm{a}-\mathrm{c}$ & $7.00 \mathrm{~b}-\mathrm{d}$ & $7.33 \mathrm{~B}$ \\
\hline & 2000 & $7.00 \mathrm{~b}-\mathrm{d}$ & $5.33 \mathrm{~d}$ & $6.16 \mathrm{C}$ \\
\hline & 3000 & $6.33 \mathrm{~cd}$ & $5.33 \mathrm{~d}$ & $5.83 \mathrm{C}$ \\
\hline & Means & $7.67 \mathrm{~A}^{\prime \prime}$ & $6.73 \mathrm{~B}^{\prime \prime}$ & \\
\hline \multirow{6}{*}{ No. of roots/plantlets } & Control & $7.00 \mathrm{a}$ & $6.67 \mathrm{ab}$ & $6.83 \mathrm{~A}$ \\
\hline & 500 & $7.33 \mathrm{a}$ & $5.00 \mathrm{c}$ & $6.16 \mathrm{AB}$ \\
\hline & 1000 & $6.33 \mathrm{ab}$ & $5.00 \mathrm{c}$ & $5.67 \mathrm{~B}$ \\
\hline & 2000 & $5.66 \mathrm{bc}$ & $3.66 \mathrm{~d}$ & $4.67 \mathrm{C}$ \\
\hline & 3000 & $5.00 \mathrm{c}$ & $3.66 \mathrm{~d}$ & $4.33 \mathrm{C}$ \\
\hline & Means & $6.27 \mathrm{~A}^{\prime \prime}$ & $4.80 \mathrm{~B}^{\prime \prime}$ & \\
\hline \multirow{6}{*}{ Root length (cm) } & Control & $7.50 \mathrm{a}$ & $6.53 \mathrm{~cd}$ & $7.02 \mathrm{~A}$ \\
\hline & 500 & $7.13 \mathrm{ab}$ & $6.53 \mathrm{~cd}$ & $6.83 \mathrm{~A}$ \\
\hline & 1000 & $6.70 \mathrm{bc}$ & $6.03 \mathrm{de}$ & $6.36 \mathrm{~B}$ \\
\hline & 2000 & $6.17 \mathrm{c}-\mathrm{e}$ & $5.30 \mathrm{f}$ & $5.73 \mathrm{C}$ \\
\hline & 3000 & $5.86 \mathrm{e}$ & $5.20 \mathrm{f}$ & $5.53 \mathrm{C}$ \\
\hline & Means & $6.67 \mathrm{~A}^{\prime \prime}$ & $5.92 \mathrm{~B}^{\prime \prime}$ & \\
\hline
\end{tabular}

Means followed by the same letters in each column, row or interaction are not significantly different at $5 \%$ level.

Egypt. J. Hort. Vol. 42, No. 1 (2015) 
B
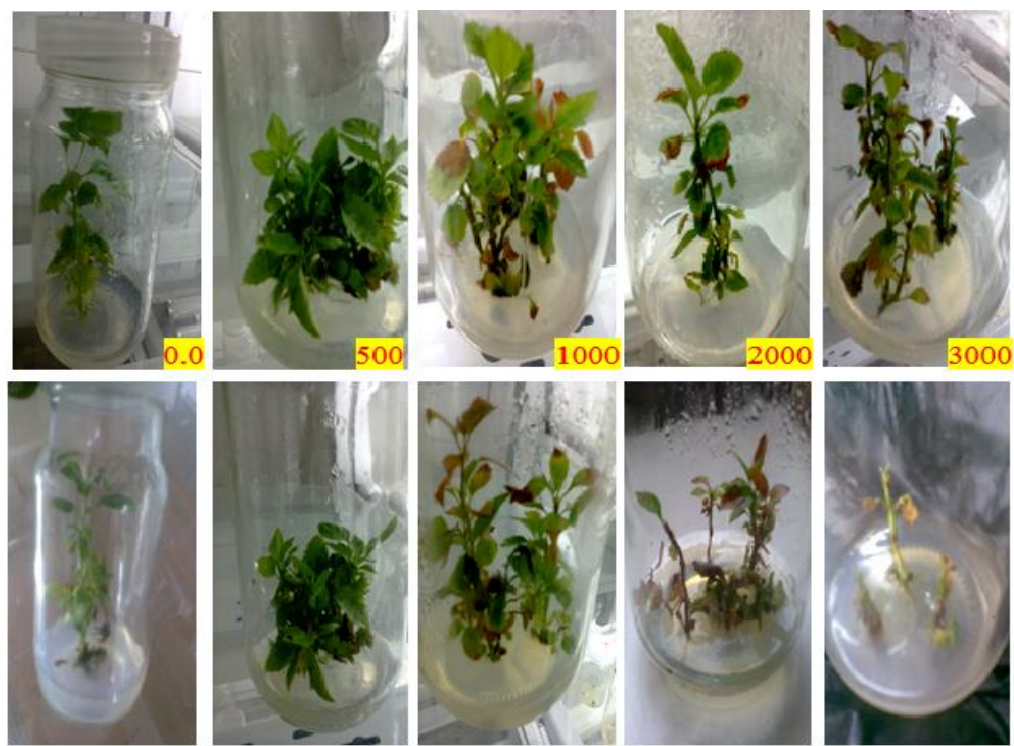

Fig. 1. Effect of $\mathrm{NaCl}$ on growth and development of apple rootstocks (B) Balady (M) MM106 in vitro.
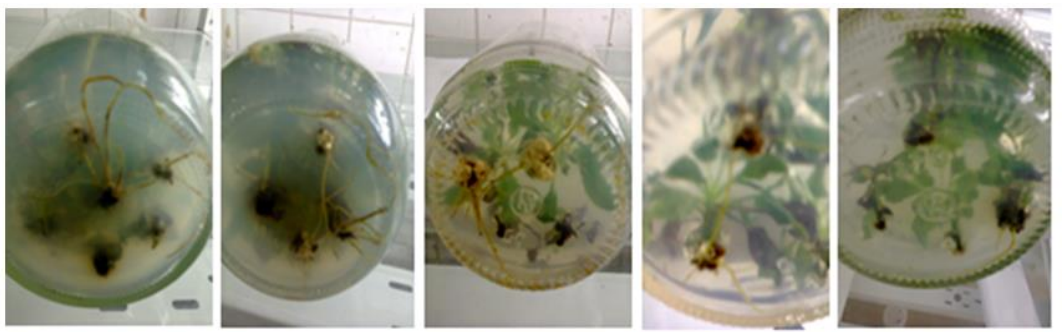

$\mathbf{M}$
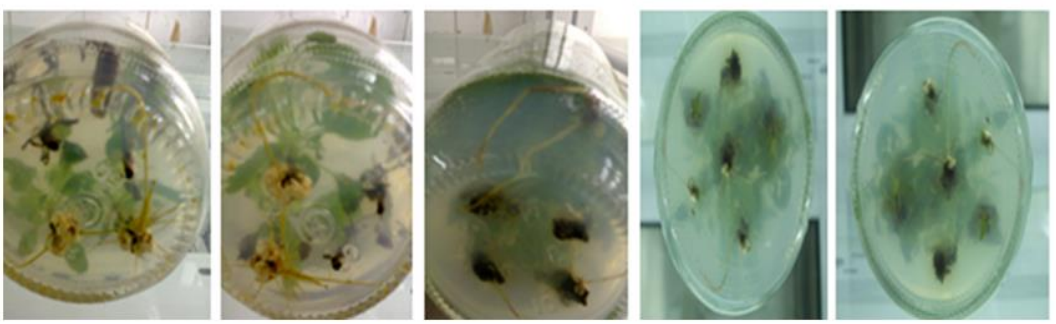

Fig. 2. Development of apple rootstocks (B) Balady (M) MM106 plants in vitro rooting in culture vessels. 


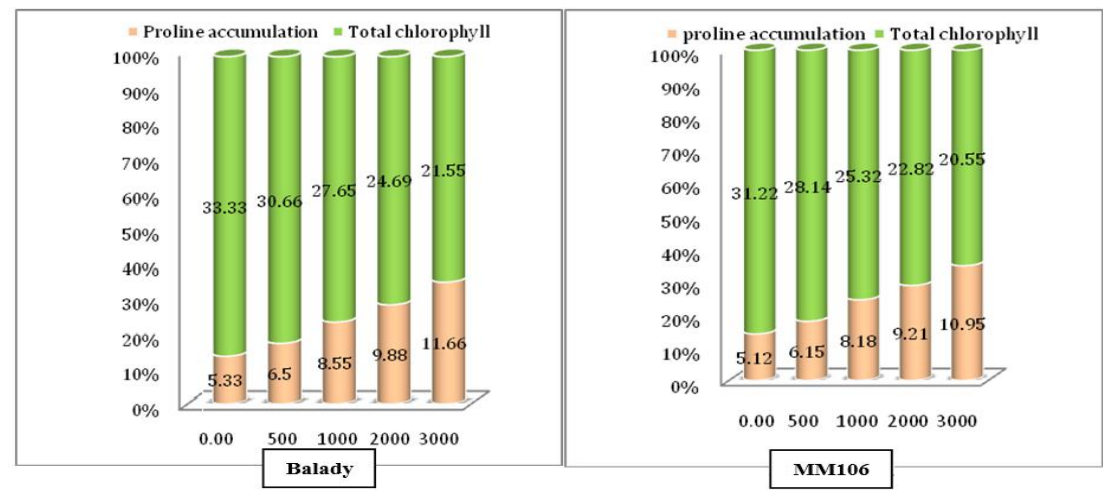

Fig. 3. Effect of salinity stress on proline accumulation and total chlorophyll of rootstock Balady and MM106.

There were differences between the control treatment and the tested concentrations of $\mathrm{NaCl}(500,1000,2000$ and $3000 \mathrm{mg} / \mathrm{l})$. At the highest concentration $3000 \mathrm{mg} / \mathrm{l}, \mathrm{NaCl}$ the total chlorophyll was 21.55 and 20.55 , if compared with control $(0.00 \mathrm{NaCl})$ which was 33.33 and 31.22 for Balady and MM106 rootstocks, respectively. Numerous studies have linked the accumulation of proline to salt stress such as, Erturk et al. (2007), who found that increasing $\mathrm{NaCl}$ concentration in vitro up to $150 \mathrm{mM}$ caused reduction of growth and chlorophyll content of sweet cherry rootstock Gisela 5 (Prunus cerasus $\times$ Prunus canescens) shoots, but had no effect on water content. Similar results were achieved by Sotiropoulos (2007) who found that increasing $\mathrm{NaCl}$ and $\mathrm{CaCl}_{2}$ concentrations in the culture medium of apple rootstock 'M4' under in vitro conditions, increased concentrations of proline and soluble sugars in plantlets, whereas, chlorophyll concentrations decreased in comparison to the control treatment. Moreover, Rayan and Awad (2013) stated that the pear plantlets content of $\mathrm{Na}, \mathrm{Cl}$ and proline were gradually increased with the raising of sodium chloride concentrations. Meanwhile, total chlorophyll content was decreased by the increasing of salt concentration in vitro.

In addition El-Sabrout (2003) mentioned that N, Na, Cl and proline contents showed a tendency of positive responses to salinity treatment, while $\mathrm{P}, \mathrm{K}, \mathrm{Ca}, \mathrm{Mg}$ and total chlorophyll contents showed negative responses of in vitro, shoot cultures of Early Superior, Flame Seedless and Thompson Seedless grape cultivars.

\section{Isozymes electrophoresis:}

Peroxidase banding patterns

Table 2 and Fig. 4 represent peroxidase electrophoresis banding patterns from fresh leaves of Balady and MM106 apple rootstocks and their treatments with different concentrations of $\mathrm{NaCl}$ (T1, T2, T3 and T4). In Balady rootstock, there were differences in bands density between control and some treatments that cause reduction in banding density. In Px1 Px2, Px7 and Px9 with relative mobility $0.30,0.43,0.67$ and 0.80 , respectively there were reducing in band density to moderate density in treatments if compared with control, which had

Egypt. J. Hort. Vol. 42, No. 1 (2015) 
high density of bands. In addition, in each of Px3 Px4, Px5 and Px11 there were some treatments manifesting high density of bands if compared with control and other treatments that appeared moderate and low density bands with relative mobilities at $0.46,0.50,0.60$ and 0.90 , respectively. While, in each of Px6, Px8 and Px10 there were no differences in banding pattern density between control and all treatments. In Px1 Px7, Px9, Px10 and Px11 with relative mobility 0.3, $0.67,0.80,0.85$ and 0.90 , respectively, there were differences in band density in some treatments if compared with control and other treatments.

Results of MM106 rootstock obviously showed similarity in band density in control and all treatments at Px8 only with relative mobility 0.70 . While, each of Px3 Px4 and Px5 in treatment (T4) manifesting low density of bands if compared with control and other treatments which appeared moderate density bands with relative mobilities at $0.46,0.50$ and 0.60 , respectively. On the other hand, there were differences in banding pattern density in some treatments which appeared density increasing in, T1, T2, T3, and T4 at Px1, Px2, Px6, Px7, Px9, Px10 and Px11 with relative mobilities $0.30,0.43,0.63,0.67,0.80,0.85$ and 0.90 , respectively, if compared with control. The results of isozyme are in harmony with Rayan et al. (2010) and Rayan et al. (2014).

TABLE 2. Densitometric analysis for leaf peroxidase isozyme of two apple rootstocks treated with four concentrations of sodium chloride.

\begin{tabular}{|c|c|c|c|c|c|c|c|c|c|c|c|}
\hline \multirow{2}{*}{$\begin{array}{l}\text { Peroxidase } \\
\text { Groups }\end{array}$} & \multirow{2}{*}{$\begin{array}{l}\text { Rebative } \\
\text { Mobility }\end{array}$} & \multicolumn{5}{|c|}{ Balady } & \multicolumn{5}{|c|}{ MM106 } \\
\hline & & C & T 1 & T2 & T3 & T4 & C & T 1 & T2 & T3 & T4 \\
\hline Pxl & $\mathbf{0 . 3 0}$ & $\mathbf{1}^{++}$ & $\mathbf{1}^{+}$ & $\mathbf{1}^{++}$ & $\mathbf{1}^{++}$ & $1^{+}$ & $1^{+}$ & $\mathbf{1}^{+}$ & $\mathbf{1}^{++}$ & $\mathbf{1}^{+}$ & $\mathbf{F}$ \\
\hline Pxe & 0.43 & $1^{++}$ & $1^{+}$ & $1^{+}$ & $1^{++}$ & $1^{+}$ & $1^{+}$ & $1^{++}$ & $1^{+}$ & $1^{+}$ & $1^{+}$ \\
\hline Px3 & 0.46 & $\overline{1}^{+}$ & $1^{+7}$ & $\mathbf{1}^{+}$ & $1^{+7}$ & $\mathbf{1}^{+}$ & $\mathbf{1}^{+}$ & $1^{+}$ & $\mathbf{1}^{+}$ & $\mathbf{1}^{+}$ & $\mathbf{1}$ \\
\hline Px4 & 0.50 & $1^{+}$ & $1^{++}$ & $1^{+}$ & $1^{++}$ & $\mathbf{1}^{-}$ & $1^{+}$ & $1^{+}$ & $\mathbf{1}^{+}$ & $1^{+}$ & $\mathbf{r}$ \\
\hline P.5 5 & 0.60 & $\mathbf{1}^{+}$ & $\mathbf{1}^{+7}$ & $\mathbf{1}^{+}$ & $1^{\#}$ & $\mathbf{1}^{-}$ & $\mathbf{1}^{+}$ & $1^{+}$ & $\mathbf{1}^{+}$ & $\mathrm{I}^{+}$ & I \\
\hline Pa6 & 0.63 & $1^{\#}$ & $1^{\#}$ & $1^{+4}$ & $1^{+7}$ & $1^{\#}$ & $1^{+}$ & $1^{\#}$ & $\mathbf{1}^{+7}$ & $1^{+}$ & $1^{+7}$ \\
\hline PA7 & 0.67 & $1^{++}$ & $1^{++}$ & $1^{++}$ & $1^{++}$ & $\mathbf{1}^{-}$ & $1^{+}$ & $1^{+}$ & $1^{++}$ & $1^{++}$ & $\mathbf{r}$ \\
\hline PA8 & 0.70 & $1^{+7}$ & $1^{+7}$ & $1^{++}$ & $1^{++}$ & $1^{+1}$ & $1^{+7}$ & $1^{+}$ & $\mathbf{1}^{++}$ & $\mathbf{1}^{++}$ & $1^{++}$ \\
\hline PX9 & 0.80 & $1^{++}$ & $1^{++}$ & $1^{++}$ & $1^{+}$ & $1^{++}$ & $1^{+}$ & $1^{+}$ & $\mathbf{1}^{+}$ & $1^{++}$ & $1^{++}$ \\
\hline Px10 & 0.85 & $1^{+7}$ & $\mathbf{1}^{++}$ & $1^{++}$ & $1^{+7}$ & $1^{++}$ & $1^{+7}$ & $1^{+7}$ & $\mathbf{1}^{+7}$ & $\mathbf{1}^{++}$ & $\mathbf{1}^{+}$ \\
\hline Pxdl & 0.90 & $\mathbf{1}^{-}$ & $1^{+}$ & $\mathbf{1}^{+}$ & $1^{+}$ & $1^{+}$ & $\mathbf{1}$ & $1^{+}$ & $\mathbf{1}^{+}$ & $1^{+}$ & $\mathbf{r}$ \\
\hline
\end{tabular}

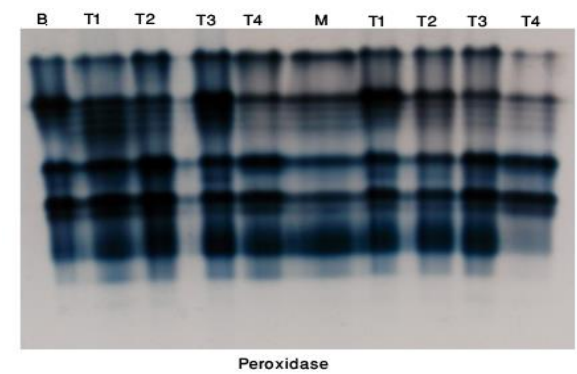

Fig. 4. Leaf peroxidase isozyme banding patterns for two apple rootstocks treated with four concentrations of sodium chloride.

Egypt. J. Hort. Vol. 42, No. 1 (2015) 
Poly phenyl oxidase banding pattern

Table 3 and Fig. 5 represent poly phenyl oxidase electrophoresis banding patterns among fresh leaves of Balady and MM106 apple rootstocks and their treatments with different concentrations of $\mathrm{NaCl}$ (T1, T2, T3 and T4). In Balady rootstock, there were differences in banding patterns density between control and all treatments that have increasing in banding density in $\mathrm{T} 1, \mathrm{~T} 2, \mathrm{~T} 3$ and $\mathrm{T} 4$ at PPO1, PPO7 and PPO8. On the other hand, there were a reduction in banding density in each of T1, T2 and T3 treatments with relative mobilities $0.10,0.70$ and 0.80, respectively at PPO2, PPO3,PPO4, PPO5 and PPO6 in compared to control. Results of MM106 rootstock obviously showed similarity in band density in control and all treatments at PPO5, PPO7 and PPO8 with relative mobility 0.45 , 0.70 and 0.80 , respectively. While, there were a reduction in banding density in each of T1 and T4 treatments at PPO1, PPO4 and PPO6 with relative mobilities $0.10,0.40$ and 0.50 , respectively in compared to control. On the other hand, there were differences in banding pattern density in some treatments, which appeared density increasing in: $\mathrm{T} 1, \mathrm{~T} 2, \mathrm{~T} 3$, and $\mathrm{T} 4$ at $\mathrm{PPO} 2$ and $\mathrm{PPO} 3$ with relative mobilities 0.20 and 0.30 , respectively, if compared with control. These results obtained herein are in harmony with Rayan et al. (2010) and Rayan et al. (2014), who clarified that peroxidase and poly phenyl oxidase banding patterns represent differences in density of bands with increase or decrease and absent of bands in treatments in comparis on with control in plum and pear cultivars .

TABLE 3. Densitometric analysis for leaf poly phenol oxidase isozyme of two apple rootstocks treated with four concentrations of sodium chloride.

\begin{tabular}{|c|c|c|c|c|c|c|c|c|c|c|c|}
\hline BlyPhenyl & Relative & & & Bala & & & & & MMI & & \\
\hline pxidase & Mobility & C & T1 & T2 & T3 & T4 & C & $\mathbf{T}$ & T2 & T3 & T4 \\
\hline Pol & 0.10 & $1^{+}$ & $1^{+}$ & $1^{+}$ & $1^{+}$ & $1^{++}$ & $1^{++}$ & $1^{++}$ & $1^{++}$ & $1^{++}$ & $1^{+}$ \\
\hline Pos & 0.20 & $1^{++}$ & $1^{+}$ & $1^{++}$ & $1^{++}$ & $1^{++}$ & $1^{+}$ & $1^{+1}$ & $1^{+}$ & $\mathbf{1}^{++}$ & $1^{+H}$ \\
\hline$P O 3$ & 0.30 & $1^{+}$ & $\mathbf{1}^{-}$ & $1^{+}$ & $1^{++}$ & $1^{++}$ & $\mathbf{1}^{+}$ & $\mathbf{1}^{-}$ & $1^{++}$ & $1^{+}$ & $1^{++}$ \\
\hline PO4 & 0.40 & $1^{+7}$ & $1^{+1}$ & $1^{+}$ & $1^{+}$ & $1^{+7}$ & $1^{++}$ & $\mathbf{1}^{+}$ & $1^{+7}$ & $1^{++}$ & $1^{+}$ \\
\hline$P \alpha$ & 0.45 & $1^{+1}$ & $1^{+}$ & $1^{+}$ & $1^{+}$ & $1^{+7}$ & $\mathbf{1}^{++}$ & $1^{+1}$ & $1^{+1}$ & $1^{++}$ & $1^{+7}$ \\
\hline PO6 & 0.50 & $1^{++}$ & $1^{+1}$ & $1^{+}$ & $1^{+}$ & $1^{++}$ & $1^{++}$ & $1^{+}$ & $1^{++}$ & $1^{++}$ & $1^{++}$ \\
\hline POT & 0.70 & $1^{+}$ & $1^{+}$ & $\mathbf{1}^{+}$ & $1^{++}$ & $1^{++}$ & $1^{++}$ & $1^{+}$ & $\mathbf{1}^{+}$ & $\mathbf{l}^{++}$ & $1^{+}$ \\
\hline $\mathrm{POB}$ & 0.80 & $1^{+}$ & $1^{++}$ & $1^{++}$ & $1^{++}$ & $1^{++}$ & $1^{++}$ & $1^{++}$ & $1^{++}$ & $1^{++}$ & $1^{++}$ \\
\hline
\end{tabular}

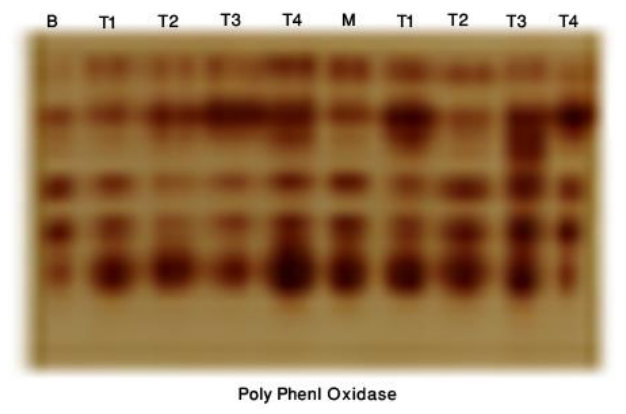

Fig. 5. Leaf Poly rhenol Oxidase isozyme banding patterns for two apple Rootstocks treated with four concentrations of sodium chloride.

Egypt. J. Hort. Vol. 42, No. 1 (2015) 


\section{Alcohol dehydrogenase banding patterns}

Table 4 and Fig. 6 illustrated alcohol dehydrogenase (ADH) electrophores is banding patterns from fresh leaves of Balady and MM106 apple rootstocks and their treatments with different concentrations of $\mathrm{NaCl}$ (T1, T2, T3 and $\mathrm{T} 4) . \mathrm{In}$ Balady rootstock, data demonstrated similarity in band density in control and all treatments at Adh3, Adh4 and Adh5 with relative mobilities 0.50, 0.56 and 0.60, respectively. Meanwhile, there were differences in bands den sity between control and some treatments in banding density in each of T1, T2 and T4 at Adh6 and Adh7 with relative mobilities 0.80 and 0.90 , respectively, if compared with control. On the other hand, there was decreasing in banding density in T1 to low density in compared with moderate density in each of control and other treatments at Adh 1 and Adh2 with relative mobilities 0.30 and 0.40 , respectively. Results of MM106 rootstock obviously showed similarity in band density in control and all treatments at Adh2, Adh3, Adh4, Adh5 and Adh6 with relative mobilities 0.40, $0.50,0.56,0.60$ and 80 , respectively. While there were differences in banding pattern density in some treatments and control at Adh1 and Adh7 with relative mobilities 0.30 and 0.90 , respectively. These results are in harmony with Marquard and Chan (1995) who found that ADH produced a fast monomorphic region and a slower polymorphic region with seven different banding patterns.

TABLE 4. Densitometric analysis for leaf alcohol dehydrogenase isozyme of two apple rootstocks treated with four concentrations of sodium chloride.

\begin{tabular}{|c|c|c|c|c|c|c|c|c|c|c|c|}
\hline Allohol & Relative & \multicolumn{5}{|c|}{ Balady } & \multicolumn{5}{|c|}{ MM106 } \\
\hline Dehydroogenase & Mobility & C & $\mathrm{Tl}$ & T2 & T3 & $\mathbf{T}$ & C & $\mathrm{T}$ & T2 & T3 & T4 \\
\hline Adhl & 0.30 & $1^{+}$ & l & $1^{+}$ & $1^{+}$ & $1^{+}$ & $1^{+}$ & $1^{+}$ & 1 & $1^{+}$ & 1 \\
\hline Adhe & 0.40 & $1^{+}$ & $\mathbf{l}^{*}$ & $1^{+}$ & $\Gamma^{+}$ & $1^{+}$ & $1^{+}$ & $1^{+}$ & $1^{+}$ & 1 & $1^{+}$ \\
\hline Adh 3 & 0.50 & $1^{+}$ & $1^{+}$ & $1^{+}$ & $I^{+}$ & $1^{+}$ & $1^{+}$ & $1^{+}$ & $1^{+}$ & $1^{+}$ & $1^{+}$ \\
\hline Adh4 & 0.56 & $1^{+}$ & $1^{+}$ & $1^{+}$ & $\Gamma^{+}$ & $1^{+}$ & $1^{+}$ & $\mathbf{l}^{+}$ & $1^{+}$ & $1^{+}$ & $1^{+}$ \\
\hline Adb & 0.60 & $1^{+}$ & $1^{+}$ & $\mathbf{1}^{+}$ & $I^{+}$ & $1^{+}$ & $1^{+}$ & $1^{+}$ & $1^{+}$ & $1^{+}$ & $1^{+}$ \\
\hline Adb6 & 0.80 & $1^{++}$ & $1^{++}$ & $1^{++}$ & $\mathrm{I}^{++}$ & l & $1^{++}$ & $1^{++}$ & $1^{++}$ & $1^{++}$ & $1^{++}$ \\
\hline Adh 7 & 0.90 & $1^{+}$ & $1^{+}$ & $\mathbf{l}^{*}$ & $\Gamma^{+}$ & $\mathbf{l}^{*}$ & $1^{+H}$ & $1^{+F}$ & $1^{+}$ & 1 & $\mathbf{l}^{*}$ \\
\hline
\end{tabular}

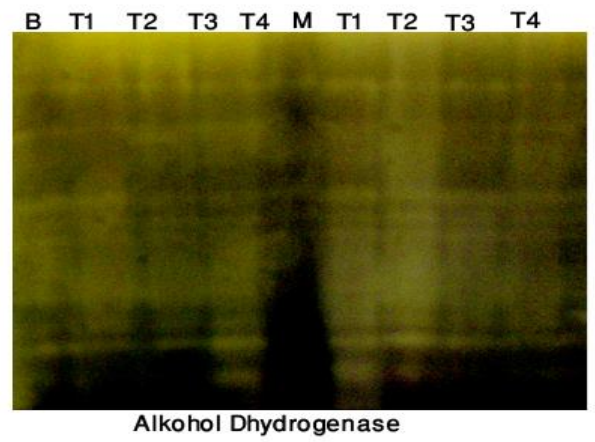

Fig. 6. Leaf alcohol dehydrogenase isozyme banding patterns for two apple rootstocks treated with four concentrations of sodium chloride

Egypt. J. Hort. Vol. 42, No. 1 (2015) 
Malate dehydrogenase banding pattern

Table 5 and Fig. 7 represent malate dehydrogenase (MDH) electrophoresis banding atterns among fresh leaves of Balady and MM106 apple rootstocks and their treatments with different concentrations of $\mathrm{NaCl}$ (T1, T2, T3 and T4). In Balady rootstock, data showed similarity in band density in control and all treatments at Mdh2 and Mdh4 with relative mobilities 0.40 and 0.60 , respectively. Meanwhile, there were differences in bands density between control and some treatments in banding density in each of T1, T2 and T4 at Mdh3 and Mdh6 with relative mobilities 0.50 and 0.90, respectively, if compared with control. On the other hand, there were increasing in band density to moderate density in all treatments if compared with control, which had low density of bands.

TABLE 5. Densitometric analysis for leaf malate dehydrogenase isozyme of two apple rootstocks treated with four concentrations of sodium chloride.

\begin{tabular}{|c|c|c|c|c|c|c|c|c|c|c|c|}
\hline \multirow{3}{*}{$\begin{array}{l}\text { Malate } \\
\text { Dehydroogenase } \\
\text { Groups } \\
\text { Mdhl }\end{array}$} & \multirow{2}{*}{$\begin{array}{l}\text { Rehative } \\
\text { Mobility }\end{array}$} & \multicolumn{5}{|c|}{ Balady } & \multicolumn{5}{|c|}{ MML06 } \\
\hline & & C & Tl & $\mathrm{T} 2$ & T3 & T4 & C & Tl & T2 & T3 & T4 \\
\hline & 0.30 & $l^{\circ}$ & $\mathbf{1}^{+}$ & $\mathrm{l}^{+}$ & $1^{+}$ & $1^{+}$ & $\mathrm{l}^{+}$ & $1^{+}$ & $\mathrm{l}^{+}$ & $1^{+}$ & $1^{+}$ \\
\hline Mdhe & 0.40 & $\mathrm{l}^{+}$ & $\mathbf{l}^{+}$ & $\mathrm{l}^{+}$ & $I^{+}$ & $\mathbf{l}^{+}$ & $1^{+}$ & $\mathbf{1}^{+}$ & $\mathrm{l}^{+}$ & $\mathrm{l}^{+}$ & $\mathrm{l}^{+}$ \\
\hline Mdh3 & 0.50 & $\mathrm{l}^{++}$ & $1^{+}$ & $1^{+}$ & $I^{+}$ & 1 & $1^{++}$ & 1 & $1^{+}$ & $1^{+}$ & $1^{+}$ \\
\hline Mdh4 & 0.60 & $\mathbf{l}^{+}$ & $\mathbf{l}^{+}$ & $\mathbf{l}^{+}$ & $I^{+}$ & $\mathbf{l}^{+}$ & $\mathbf{l}^{+}$ & $\mathrm{I}^{+}$ & $\mathbf{l}^{+}$ & $\mathrm{l}^{+}$ & $\mathbf{1}^{+}$ \\
\hline MdfE & 0.80 & $\mathbf{l}^{-}$ & $\mathrm{l}^{+}$ & $1^{+}$ & $I^{+}$ & $\mathrm{I}^{+}$ & $\mathrm{I}^{-}$ & $\mathrm{I}^{+}$ & $1^{+}$ & $\mathrm{l}^{+}$ & $1^{+}$ \\
\hline Mdl6 & 0.90 & $\mathrm{l}^{+}$ & $1^{\circ}$ & $\mathbf{1}^{-}$ & $\mathrm{I}^{+}$ & 1 & $\mathrm{l}^{+}$ & $\mathrm{l}^{+}$ & $1^{\circ}$ & 1 & $1^{+}$ \\
\hline
\end{tabular}

$\begin{array}{llllllllll}\text { B } & \text { T1 } & \text { T2 } & \text { T3 } & \text { T4 } & \text { M } & \text { T1 } & \text { T2 } & \text { T3 } & \text { T4 }\end{array}$

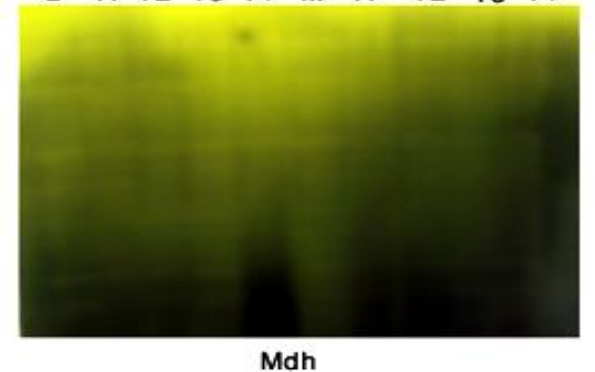

Fig. 7. Leaf malate dehydrogenase isozyme banding patterns for two apple rootstocks treated with four concentrations of sodium chloride.

Results of MM106 rootstock obviously showed similarity in band density in control and all treatments at Mdh1, Mdh2 and Mdh4 with relative mobilities $0.30,0.40$ and 0.60 , respectively. While, there were a reduction in banding density in control with low density of band compared with all treatments at Mdh5 with relative mobility 0.80 . On the other hand, data illustrated differences in banding density between control and treatments at Mdh3 and Mdh6 with

Egypt. J. Hort. Vol. 42, No. 1 (2015) 
relative mobilities 0.50 and 0.90 , respectively. These results are in agreement with Biruk and Kazlovskaya (2008) who found that MDH gave two monomorphic areas, but only some bands were variable between the studied apple cultivars.

In conclusion, it can be concluded that the high concentration of $\mathrm{NaCl}$ caused a negative influence on all studied parameters. Increasing $\mathrm{NaCl}$ concentrations were reflected on the behavior of different explants under in vitro conditions.

Finally, a specific advantage of salinity stress is to develop a range of tolerant lines. All variant regenerated plantlets were acclimatized to be transplanting into the permanent field for further studies and to be used in breeding programs and selection procedures.

\section{References}

Ashraf, M. and Akram, N.A. (2009) Improving salinity tolerance of plants through conventional breeding and genetic engineering. Biotechnol. Adv., 27, 744-752.

Ashraf, M., Akram, N.A. Mehboob-Ur-Rahman and Foolad, M.R. (2012) Markerassisted selection in plant breeding for salinity tolerance. Methods Mol. Biol., 913, 305-33.

Bates, L.S., Waldron, R.P. and Teaxe, I.W. (1973) Rapid determination of free proline for water stress studies. Plant and Soil, 39, 205-207.

Batlle, I. and Aleston, F.H. (1994) Isozyme aided selection in the transfer of mildew (Podosphaera leucatricha) resistance from Malus hupehensis to the cultivated apple. Euphytica, 77, 11-14.

Biruk, A. and Kazlovskaya, Z. (2008) Prospects for using of isozyme markers in identification of apple cultivars. Sodininky ste Ir Daržininkyste. Mokslo Darbai. 27(2), 359-364.

Chinnusamy, V., Jagendorf, A. and Zhu, J.K. (2005) Understanding and improving salt tolerance in plants. Crop Sci., 45, 437-448.

El-Agamy, S.Z, Rafat, A.A., Mostafa, M., Mokhtar, S. and Marwa T. El-Mahdy (2010) In vitro Salt and Drought Tolerance of Manfalouty and Nab El-Gamal Pomegranate Cultivars, Australian Journal of Basic and Appl. Sci., 4 (6), 1076-1082, ISSN 1991-8178.

El-Sabrout, M.B. (2003) Micropropagation and salt tolerance evaluation in some grape cultivars. II- Salt tolerance evaluation. J. Agric Sci. Mansura Univ., 28 (11), 6833-6855.

Erturk, U., Sivritepe, N., Erlikaya, C.Y., Bor, M., Ozdemir, F. and Turkan, I. (2007) Responses of the cherry rootstock to salinity in vitro. Biologia Plantarum, 51 (3), 597-600.

Jonathan, F.W. and Weeden, N.F. (1990) Visualization and interpretation of plant isozymes. Isozymes in plant Biology. D.E. Soltis and P.S. Soltis (Ed.), London Chapman and Hall, pp. 5-45. 
Marquard, R.D. and Chan, C.R. (1995). Identifying Crabapple Cultivars by Isozymes. J. Amer. Soc. Hort. Sci., 120 (5), 704-709.

Molassiotis, A.N., Sotiropoulos, T.E., Tanou, G., Kofidis, G., Diamantidis, D. and Therios, I.N. (2006) Antioxidant and anatomical responses in shoot culture of the apple rootstock MM 106 treated with $\mathrm{NaCl}, \mathrm{KCl}$, mannitol or sorbitol. Biologia Plantarum, 50, 61-68.

Murashige, T. and Skoog, F. (1962) A revised medium for rapid growth and bioassay with tobacco tissue culture. Physiol. Plant, 15, 473-495.

Naeniei, M., Khoshgoftarmanesh, A. and Fallahi, E. (2006) Partitioning of chlorine, sodium, and potassium and shoot growth of three pomegranate cultivars under different levels of salinity. J. Plant Nutrition, 29 (10), 1835-1843.

Rayan, A.O. and Awad, N.A. (2013) Induction Somaclonal Variation in Pear Plants (Pyrus Communis var. Betulifolia) for Salinaty Tolerance Through Tissue Culture Technique. Egypt. J. Hort., 40 (1), 37- 45.

Rayan, A.O., Zeinab A. Abo Rekab and Mohamed, S.Y. (2010) In vitro studies on genetic variations of some plum cultivars using gamma irradiation from cobalt 60 Egypt. J. Appl. Sci., 25 (4B), 218-233.

Rayan, A.O., Mohamed, S.Y. and Salwa El-Habashy (2014) In vitro studies of different chemical mutagens on some apple rootstock (Malus domestica Borkh). J. Agri. Chemistry and Biotechn., Mansoura Univ., 5 (12), 305-318

Ryugo, K. (1988) Fruit culture: Its Science and Art, chapter 10: Nursery practices and management. John Wiley \& Sons, Inc. pp. 223-243.

Sivritepe, N. and Eris, A. (1999) Determination of Salt Tolerance in Some Grapevine cultivars (Vitis vinifera L.) under in vitro conditions. Turkish J. Biology, 23, 473-485.

Snedecor, G. W. and W. G. Cochran (1980) "Statistical Methods" $7^{\text {th }}$ ed., The Iowa State Univ. Press, Ames, Iowa, U.S.A. p. 593.

Sotiropoulos, T.E., Mouhtaridou, G.N., Thomidis, T., Tsirakoglou, V., Dimassi, K.N. and Therios, I.N. (2005) Effects of different N-sources on growth, nutritional status, chlorophyll content, and photosynthetic parameters of shoots of the app le rootstock MM 106 cultured in vitro. Biologia Plantarum, 49, 297-299.

Sotiropoulos, T.E. (2007) Effect of $\mathrm{NaCl}$ and $\mathrm{CaCl}$ on growth and on tents of minerals, chlorophyll, proline and sugars in the apple rootstock M4 cultured in vitro. Biologia Plantarum, 51 (1), 177-180.

Sotiropoulos, T.E., Dimassi, K.N., Tsirakoglou, V., Therios, I.N. (2006) Responses of two Prunus rootstocks to $\mathrm{KCl}$ induced salinity in vitro. Biologia Plantarum, 50 (3), 477-480.

Therios, I.N. and Misopolinos, N.D. (1989) Differences in tolerance to sodium chloride salinity between three commercial apple rootstocks. Soilless Culture, 5 (1), 55-71.

Egypt. J. Hort. Vol. 42, No. 1 (2015) 
Vijayan, K., Chakraborti, S.P. and Ghosh, P.D. (2003) In vitro screening of mulberry (Morus spp.) for salinity tolerance. Plant Cell Rep., 22, 350-357.

Vitaglino C., Mensuali-Sodi A. and Blando, F. (1992) Effect of $\mathrm{NaCl}$ on quince (Cydonia oblonga) tissue culture. Acta Hort., 300, 347-352.

Wendel, J.S. and Weeden, N.F. (1989) Visualization and interpretation of plant isozymes. In isozymes in Plant Biology. Soltis, D.E. and Soltis, P.S. (Ed.), Portland, Oregon: Dioscorides Press.

Zhu, J.K. (2001) Plant salt tolerance. Trends Plant Sci., 6, 66-71.

(Received 24/9/2014; accepted 27/1/2015) 


$$
\begin{aligned}
& \text { تأثير الإجهاد الملحي على الكلس والتبتات الناتجة من اصول التفاح } \\
& \text { في المعمل } \\
& \text { أحمد عثمان ريان } \\
& \text { قسم بحوث تربية الفاكهة و الاشجار الخثبية و الزينة ـ معهد بحوث البساتين- مركز }
\end{aligned}
$$

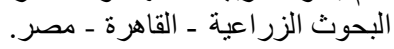

تمثل ملوحة التربة قلق للباحثين و هي من الامور الهامة فى برامج تربية الفاكهة

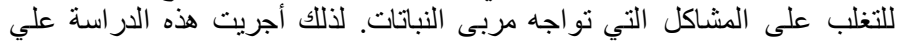

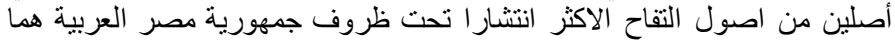

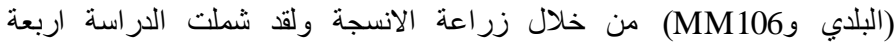

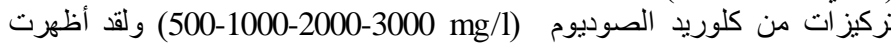
الدراسة.

تأثر جميع الصفات تحت الدراسة (نسبة بقاء الكلس - نسبة تكون النباتات -

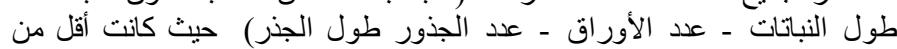

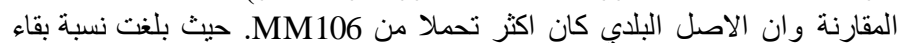

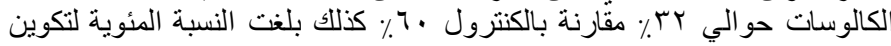

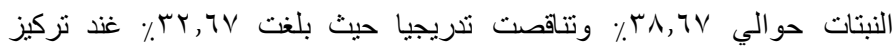

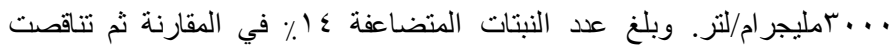

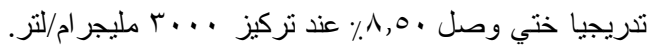

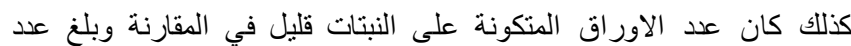

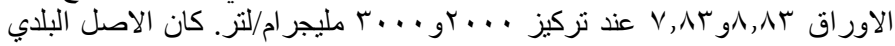

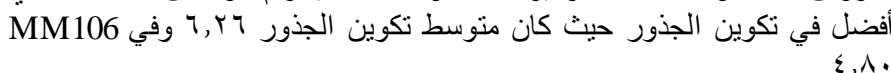

ومن الناحية الكيميائية ادي زيادة تركيزات الملوحة الى زيادة تركيز البرولين

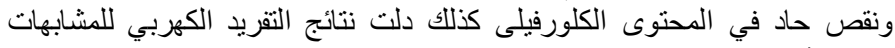

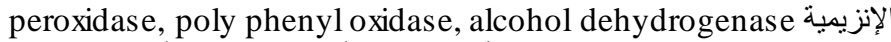
and malate dehydrogenase

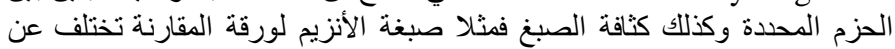

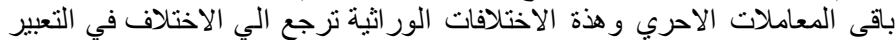
الجيني تحت تأثير المستويات المحتلفة من الملوحة. الورة

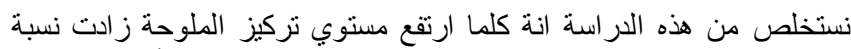

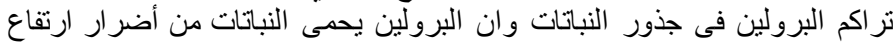

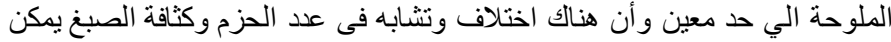

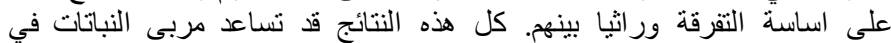
استتباط اصول و أصناف تتحمل مستويات اعلى من لن الملوحة.

كذلك كان الأصل البلدي أفضل في جميع الصفات تحت الدراسة ولذللك بمكن التوصية بإكثاره وزيادة التوسع في استخدامه كأصل للتطعيم عليه. 